\title{
AMERICA'S HISTORICAL MEDIA FASCINATION WITH RUSSIA: THE NEW YORK TIMES AND RUSSIAN JEWS 1851- 1905
}

\author{
Haylee Behrends ${ }^{1}$ \\ ${ }^{1}$ Author affiliation: Charles University, Prague, Czech Republic. \\ *Corresponding author: Haylee Begrends - hayleebehrends@gmail.com
}

Received: 25.01.2021; Accepted: 29.03.2021; Published: 17.5. 2021

Doi: https://doi.org/10.46473/WCSAJ27240606/17-05-2021-0005

Category: Research paper

\begin{abstract}
This article details how one newspaper The New York Times portrayed Russian Jews between 1851 and 1905 and seeks to answer how and why there were certain periods of time that reporting on Russian Jews peaked in the newspaper. The results demonstrated that during time periods of significant immigration of Russian Jews to the United States, namely 1881-1882, 1890-1893, and 1903-1905, The New York Times reported significantly more about Jewish persecution in Russia. The results also demonstrate that news stories about Russia may have appealed to American citizens, particularly when the portrayal of Russia was either sensationalized or negative. The methods used were analysis of historical The New York Times newspaper articles as well as quantification of articles used through categorizing by date of publication. For example, in the 1870s 6 articles related to Russian Jews were published in The New York Times, 80 in the 1880s, 170 in the 1890s, and 407 between 1900 and 1905. The extent of which Americans were interested in Russia is subject for later research by comparison to how other newspapers portrayed Russia during this same immigration period. This research only focuses on one source as a baseline to discover trends in reporting within an individual source.
\end{abstract}

Keywords: Historical Sociology, The New York Times, Russian Empire, United States, Newspaper Media, Russian Jews 
WORLD COMPLEXITY SCIENCE ACADEMY JOURNAL| Vol. 2 Issue 1, 5 | Spring 2020

\section{Introduction}

United States media is fascinated with Russia and in particular, negative portrayal of Russia. U.S. media criticizes the Russian president and alludes to Russian deception, hacking, and other negative connotations when describing Russia. This is not a new trend in the United States. Already in the mid to late nineteenth century the United States negativity portrayed the Russian Empire. To be sure, there were positive portrayals as well and the U.S. deemed Russia to be a friend and not yet its "other" in terms of national identity as the Soviet Union would later become during the bulk of the twentieth century. Nonetheless, starting in the 1880s and accelerating in the 1890s and early 1900s, newspapers reported extensively on Russia's domestic condition, and in particular on the treatment of its Jewish population. This article intends to analyze how one newspaper, The New York Times, reported on Russia's treatment of its Jews from the time of the establishment of the Times in 1851 until 1905, seeking to avoid reports on the Russian revolutionary period. Analysis of the Times offers a clear picture of how reporting of Russia's Jews transformed and the focus on one newspaper source acts as a control in determining other factors that may have contributed to such attention given to this particular topic. The media has the ability to influence our perceptions, and this article demonstrates how one media source contributed to American perception of the Russian Empire through its emphasis on Russia's treatment of its Jewish population. Through analysis of trends in the numbers of articles published each year and each decade between 1851 to 1905 pertaining to Jews in the Russian Empire, this article seeks to answer if there were trends in reporting and what factors may have contributed to an increase of articles related to Russia's Jewish population.

\section{Theoretical review}

Norman Saul, a master in the field of research devoted to Russia and America's historical relations outlined in detail the role that Russia's treatment of its Jews played in America's perception of the Russian Empire. As Saul points out, throughout the 1860s and 1870s, although Jewish restrictions were still intact in the Russian Empire, their enforcement was relatively laxed until the 1880s (Saul, 1996). He argues that Jews who immigrated to America from places such as Odessa, Kiev, and Minsk influenced American perception of the Russian Empire and subsequently expressed sympathies towards the treatment of Jews in the Russian Empire. Saul offers specific and detailed examples of Jewish immigrants who faced problems in Russia when they returned there after obtaining U.S. citizenship. Based on Saul's analyses of the significant rise in immigration of Jews from the Russian Empire (most often from the regions of Ukraine and Poland), one can discern that as more Jews immigrated to the United States, the impression of Russia's treatment of Jews worsened.

At the turn of the twentieth century, negative reports on Russian Jews reached its zenith in American newspapers. There were 300 pogroms between 1903 and 1906 in Russia. According to most sources this resulted from non-Jewish Russians scapegoating Russian Jews for economic problems and other hardships that Russian citizens faced. Stuart E. Knee argues that the American people were sympathetic to the plight of Russian Jews prior to any real intervention by the U.S. government. As Saul also mentions, Knee states that "eye-witness accounts of refugees" contributed to American "disgust" towards Russia's treatment of its Jews (Knee, 1989). Americans protested, staged rallies, organized committees, and sent letters, petitions, and addresses to President Roosevelt denouncing Russian Jewish persecution.

Not only did Jews petition the U.S. president to intervene on their behalf, but they also took matters into their own hands as well by donating money to the Japanese government to assist 
them in defeating Russia during the Russo-Japanese War (1904-05). The Jewish community in American, regardless of their background being either Russian, German, English, or having been long assimilated into American society, came together to speak out against Russian Jewish persecution and those in prominent positions such as diplomacy, business, and media, were able to influence public perception of the Russian Empire. Knee claims that Nicholas II heeded American pressure to improve Russia's treatment of Jews when he retaliated against governors of anti-Semitic territories and dismissed Bessarabia's governor after the Kishinev massacre. The tsar did this arguably because he needed friends in his conflict with Japan and sought to stay on friendly terms with the United States (Knee, 1989).

Simultaneously during the same period that American sympathy towards Russian Jews grew, John Higham argues that anti-Semitism also grew between 1870 and 1900 and it was at that time that the favourable position of Jews in American society began to diminish (Higham ,1957). While correlation does not prove causation, it is important to note that this is the same time period that Jewish immigration to the United States drastically increased and when more Jews immigrated to America from Eastern Europe than from other countries like they previously had, namely Germany and England. Certain segments of Americans held antiSemitic views for similar reasons that Russians did. Jews were perceived as economically successful and model capitalists, which caused the struggling working class and farmers, often members of the Populist movement, to view Jews as adversaries (Higham, 1957). Jews were the scapegoat in America as they were in Russia, though there were not pogroms or governmental policies targeted against Jews in America.

Furthermore, American literature throughout the nineteenth century held many motifs and stereotypes about Jews, whether one can claim them to be inherently anti-Semitic is up for debate, but some are hard to argue away as being harmless (Dobkowski, 1977). The most common stereotypes were about excessive and unsavoury business practices held by Jews or they stemmed from a religious background, with Christians condemning Jewishness. Numerous newspapers and periodicals published negatively about eastern European Jews in particular and their inability to be easily assimilated into American culture. The New York Times, which extensively criticized Russia for its Jewish discrimination published numerous articles criticizing those very same Jews who had immigrated to America from Russia. The newspaper used terms such as "wretched people" and "burden" to describe Russian Jews and stated that Americans did not like to give handouts and that these Jews would add little benefit to American society ${ }^{1}$. The Times claimed Russian Jews often complained about the nature of the work they were doing after their arrival in America and were not satisfied with their compensation, which did not resonate with Americans who claimed to strongly value work. The New York Times detailed that some Americans sought restrictions on Jewish immigration to the U.S., though stated that refusing Jews outright would be equally as cruel as the actions of the tsar ${ }^{2}$.

To be sure, throughout most of the nineteenth century the United States and Russia had friendly relations. Strikingly, due to its early reporting and its front-page appearance, a short article pertaining to Russian Jews was published in the Times already in 1869. This article's brief nature of only one sentence stated that Russian Jews had petitioned their government for an extension of their "rights of religion and education". The Times stated that it was an extension, meaning that Jews already had rights of religion and education under tsar Alexander II, and

\footnotetext{
1 “The Russian Jews.”. The New York Times. May 3, 1891. Vol. XL, no. 12,381. p. 4.

2 “The Russian Refugees.". The New York Times. August 17, 1891. Vol. XL, no. 12,472. p. 4.
} 
their exercise in rights made headlines ${ }^{3}$. Only four months later, the Times reported that an old law was re-enacted that limited the rights of Jewish residence in Russia forcing Jews to move from the Bessarabia frontier to the interior of the country. The Times defended Alexander II claiming, "The impression prevails that the Emperor will disapprove of these proceedings" 4 . In 1874 the Times reported on increased intolerance of Russia towards its Jewish population citing an order by the Russian government that Jews be discharged from work at any railway companies throughout Russia. The newspaper was sceptical of this report, stating that it came from a Berlin newspaper and ought to be taken "cum grano salis", with a grain of salt ${ }^{5}$. In the 1870s, the Times was less apt to report on Jewish persecution, as it had not yet exploded as an issue to the world and because the Times was still in friendly relations with the Russian government primarily due to its friendly characterization of Alexander II.

Russia was a sensational topic in the Times for a variety of reasons pertaining to war, its leadership, social unrest, and Jewish persecution. On April 24, 1903, the Times reported about anti-Semitic riots in Kishinev. This report pertaining to one component of the infamous Kishinev massacre was buried in the middle of the newspaper on page 6 out of 16 and consisted of only a short matter-of-fact paragraph. On the front page of this issue there was an article devoted to the Russo-Japanese War. Russia still made the news, though the war between Russia and Japan and their dispute over the Chinese territory of Manchuria took precedent ${ }^{6}$.

Despite its negative portrayal of Russian persecution of its Jewish population, the Times noted the historical friendship between Russia and the United States often, and President Harrison noted it as well when he also called out Russia for its treatment of its Jews. On December 9, 1891 during his Third Annual Message, U.S. President Benjamin Harrison addressed the Senate and House of Representatives and acknowledged Russian discrimination against Jews. Harrison stated, "This Government has found occasion to express in a friendly spirit, but with much earnestness, to the Government of the Czar its serious concern because of the harsh measures now being enforced against the Hebrews in Russia. By the revival of antisemitic laws, long in abeyance, great numbers of those unfortunate people have been constrained to abandon their homes and leave the Empire by reason of the impossibility of finding subsistence within the pale to which it is sought to confine them." He went on to state that these Jews were coming to the United States in large numbers which was impacting the country; "It is also true that no race, sect, or class has more fully cared for its own than the Hebrew race. But the sudden transfer of such a multitude under conditions that tend to strip them of their small accumulations and to depress their energies and courage is neither good for them nor for us." Harrison concluded with the following statement: "The banishment, whether by direct decree or by not less certain indirect methods, of so large a number of men and women is not a local question. A decree to leave one country is in the nature of things in order to enter another--some other. This consideration, as well as the suggestion of humanity, furnishes ample ground for the remonstrances which we have presented to Russia, while our historic friendship for that Government cannot fail to give the assurance that our representations are those of a sincere

\footnotetext{
3 "Russia: Petition of the Jews to the Czar for their Rights". The New York Times. July 30, 1869. Vol. XVIII, no. 5570. p. 1.

4 "Russia: An Old Law Relating to Jews Revived-Two Thousand Ordered into the Interior". The New York Times. November 27, 1869. Vol. XIX, no. 5973. p. 3.

5 “The Emperor of Russia and the Jews". The New York Times. December 12, 1874. Vol. XXIV, no. 7251. p. 6.

6 "Massacre of Jews in Russia. Twenty-five Killed and 275 Wounded in Anti-Semitic Riots in Bessarabia". The New York Times. April 24, 1903. Vol. LII, no. 16630. p. 6.
} 
well-wisher."7 Harrison was careful not to condemn the Russian government too severely and his chief concerns were that the displaced Russian Jews would need to find another country once they left the Russian Empire, which was a growing concern in America.

By 1890, the Times described Russia's laws against Russian Jews as arousing a "strong feeling among the Jewish population of this city to take similar action, and to call upon the Government to request the Czar to repeal the obnoxious laws against the Jews in his domains". Many "NewYork Hebrews", according to the Times, hoped that Americans would unite with them to stop persecution of Russian Jews. The Times stated that the persecution of Russian Jews had already caused many Jews to immigrate to the United States and would continue to do so, taxing the country's financial resources and causing hardship to ensue for the Jewish arrivals. The Times acknowledged and explicitly cited former New York City judge Meyer S. Isaacs who they claimed believed that what could cause more resolutions concerning Jewish persecution in Russia would be the "advocacy of the cause by editors of the leading newspapers in their editorial columns" considering "Russian officials were sensitive in this respect, and carefully watched the drift of opinion as expressed in editorials and newspapers". New York Rabbi Joseph at synagogue Beth Hamedrasch Hagadol promoted action against Russian Jewish persecution through governmental action and New York Rabbi Kohler at Temple Beth El condemned Russia as the only country left in the world where Jews were not proven to be equals. ${ }^{8}$ A year later in 1891, Russians retaliated against American concern over Jewish discrimination by stating that lynching occurs in the United States against African Americans. Essentially, they pointed the accusations of non-humanitarian practices back at the United States. ${ }^{9}$ Knee alleges that President Roosevelt and Secretary of State John Hay by the early 1900s did not inherently care about the plight of Russian Jews but instead saw the situation as a political opportunity due to an upcoming election, and in general Roosevelt allegedly never much cared for Russia or its tsar. Ultimately, the American government sought nonintervention, though later repealed the 1832 Russo-American commercial treaty in 1913 on grounds that Russia did not grant all American citizens with equal and fair access to business and trade in Russia. One explanation for American disapproval of certain Russian policies was the inability of Americans to understand Russia (Cognolato, 2016, 107). One might describe this as wilful ignorance or in art due to most Americans' only access to information pertaining to Russia was what was presented to them by the media.

In 1896 the Times detailed the historic restrictive laws that Russia held towards its Jewish population. Prior to the reign of Catherine II otherwise known as Catherine the Great, Jews were banned from living in Russia altogether, until Catherine II annexed Poland to the west and inherited a significant Jewish population. Catherine II confined Jews to certain areas of settlement, otherwise known as the Pale of Settlement, which consisted of mostly western territories within the Russian Empire. Alexander, I reaffirmed these residential restrictions and enforced other restrictions on their class and commerce while, according to the Times, his successor Alexander II attempted to remove restrictions on the "Hebrew population", which amounted to 5 million individuals ${ }^{10}$.

\footnotetext{
${ }^{7}$ Harrison, Benjamin. Third Annual Message. December 9, 1891. Congress. Online. https://millercenter.org/thepresidency/presidential-speeches/december-9-1891-third-annual-message-0.

8 “The Jews in Russia: Sympathy Here for their Unhappy Condition". The New York Times. December 14, 1890. Vol. XL, no. 12,261. p. 9.

${ }^{9}$ Knee, S. E. (1989), "The Diplomacy of Neutrality: Theodore Roosevelt and the Russian Pogroms of 19031906." Presidential Studies Quarterly 19, no. 1, p.73.

${ }^{10}$ The Jews of Russia: Review of the Various Restrictive Laws Under Which They Have Lived. June 19, 1896. Vol. XLV, no. 13988. p. 6.
} 
Mass immigration of the Russian Jewish population to the United States started in 1881 after Alexander III became tsar. Russian Jewish immigration in this year was around 3,000 and over the following thirty years 1 million Jews would immigrate to the United States from Russia, with 12.1 percent of this total arriving between 1881 and 1890, 25 percent between 1891 and 1900, and 62.9 percent arriving between 1901 and 1910. The influxes in immigration were a result of pogroms in 1881, educational restrictions and strict enforcement of May Laws in 1887, expulsions from Moscow in the early 1890s, economic depression and anti-Jewish propaganda in 1899, and finally the Kishinev massacre, the Russo-Japanese War and revolution all which occurred between 1903 and 1905. Non-Jews from the Russian Empire immigrated to the United States as well between 1881 and 1910 though Jews made up 48.3 percent of the total Russian immigration (Joseph, 1914, 98-101). The greatest number of Jewish immigrants came between 1904 and 1905 as a result of "the unusual conditions existing in Russia at this time-economic unrest, revolution - which had the effect of sending over the mend as an avantgarde to prepare the way for their families" (Joseph, 1914, 128). The social and economic status of Jews leaving Russia featured on the pages of the Times. The Times outlined that thousands of Jews had been leaving Southern Russia, many of whom due to a newly passed age exemption for military service were not yet 20 years old. Additionally, many were described as being from the "poor artisan" class without possessing any capital for commencing business once they were to arrive in either England or the United States (Joseph, 1914, 17).

It is worth noting that although not all Jews who immigrated to America stayed, most were "permanent settlers". In 1907 a law was passed that required steamships to provide information regarding emigrant passengers, prior to that emigration was not well-documented. According to a report published in 1914, between 1908 and 1912 an annual average of 83,400 Jews immigrated to America and 6,660 Jews emigrated from America, while the Jewish immigrants constituted 9.7 percent of total immigrants and only 2.3 percent of total emigrants. Only 8 out of 100 Jews emigrated compared to the total immigration figures in which 32 out of 100 immigrants emigrated from the United States. Russian Jews in particular were the most likely to stay in the United States and Russian Jews were at least three times as likely to stay in America compared to other Russian minority immigrants such as the Poles ${ }^{11}$. While 1907 to 1914 falls slightly out of the scope of this article, the figures demonstrate trends in Russian Jewish immigration and emigration. Americans who worried about too many Russian Jewish immigrants settling in America did so out of the correct perception that they would in fact stay in America once they arrived there. Americans also feared the assimilability of Russian Jews and their propensity for work. There was a high number of Jewish immigrants who stated "no occupation" on their immigration forms, in fact, they held the highest proportion in this category out of all immigrants at 45.1 percent as well as the highest absolute numbers. However, Jewish immigrants also held the highest proportion of those with "skilled occupations"12.

The September following tsar Alexander II's death in May of 1881, New York City prepared for the arrival of over 500 Jewish immigrants to the United States. The Times stated that prominent New York Jews extended an invitation for South Russian Jews to come to America via correspondence with the "Alliance Israelite Universelle" headquartered in Paris. A committee sent out from Paris visited Russia and were instructed to select only the best families

\footnotetext{
${ }^{11}$ Joseph, S. (1914), “Jewish Immigration to the United States from 1881 to 1910”, New York: Columbia, pp. 134-136.

12 Joseph, S. (1914), “Jewish Immigration to the United States from 1881 to 1910”, New York: Columbia, pp. 143-144.
} 
who were "strong and healthy, able and willing to perform hard work, and who have been trained to some handicraft", emphasizing mechanics and farmers, as immigrants to America ${ }^{13}$. This article references 671 articles published by The New York Times between 1869 and 1905. There were spikes in reports on Russia's Jews in the following years 1881 (21), 1882 (41), 1890 (20), 1891 (83), 1892 (28), 1893 (17), 1903 (153), 1904 (106), and 1905 (126). The years from 1903 to 1905 are the most striking considering that articles related to Russia's Jews were published on average around twice per week whereas other years articles pertaining to Russia's Jews were published around twice per year or in some cases even less. In 1900, no articles related to Russia's Jews were published at all. From 1851, the year the Times was established, until 2 were published in 1869, there were no articles published about Russia's Jews in the newspaper. Throughout the 1870s, only 6 articles were published related to Jews in the Russian Empire compared to 80 in the 1880s, 170 in the 1890s, and 407 between 1900 and 1905. The majority of articles alluded to Jewish persecution and suffering in the Russian Empire; however, for a brief period of time in the $1880 \mathrm{~s}$, the newspaper connected Russian Jews to nihilism.

In 1880, the Times published 3 articles related to Russian Jews and 2 out of those 3 articles connected Russian Jews to nihilism. In 1881, 21 articles related to Russia were published and 5 connected Russian Jews to nihilism. By 1882, 41 articles related to Russian Jews were published and only 2 connected the Jews to nihilism. Around the world reports for both the Times headquartered in London and in New York City attempted to connect the Jewish population to nihilism. They cited that 6 out of 17 nihilists condemned for a plotted assassination attempt against the tsar were Jewish, among at least 5 other occasions of nihilist plots where a significant portion of the participants were Jewish. The Times described Jews as in the "extreme section" of nihilists and stated that the south of Russia was "overrun" by Jews. They also cite the Russian newspaper Novoya Vremya's statistics stating that 9 percent of nihilists were Jews. The Times explained the high proportion of Jews among nihilists as stemming from the "humble origins" of said Jews and the fact that they seemingly had little to lose through nihilistic and anarchistic acts ${ }^{14}$.

Simultaneously, working class Americans criticized Jews for being too successful at conducting business, causing Jews to come under scrutiny for two contradictory reasons, being both too wealthy and too poor, both too capable and too inept. The plight of the Jews was not entirely apparent to the Times prior to 1881, possibly because they were not looking for a problem with Russia as a result of their affinity for tsar Alexander II, and also because Russia's treatment of Jews caused Jews to show up on American soil seeking refuge, presenting the treatment of Russia's Jews immediately in front of the eyes of many Americans. The majority of articles published in 1882 about Russian Jews outlined Russian Jewish refugees who had just arrived in America fleeing Russian persecution.

Individual leaders of Russia impacted how the Russian Empire was reported on. The period of time when Alexander II was tsar (1855-1894), the Times tended to portray the Russian Empire favourably. This changed during the subsequent reigns of his son Alexander III and grandson Nicholas II both of whom the Times described as less progressive than Alexander II. Alexander III enacted the Edict of 1882 and further limited the rights of Jewish citizens in Russia. The plight of the Jews came under scrutiny while Russia experienced a famine in the early 1890s. The correlation to the two events is that there was an increase in Jewish persecution as a result

\footnotetext{
13 "Russian Immigrants. Preparations for the Reception of Exiled Jews from Russia". The New York Times. September 9, 1881. Vol. XXX, no. 9362. p. 8.

14 "The Jews of Russia: A Large Number of the Hebrew Race Found among the Nihilists". The New York Times. May 14, 1880. Vol. XXIX, no. 8949. p. 2.
} 
of Russians using Jews as a scapegoat for the famine and economic hardships felt by the Russian population.

\section{Conclusions}

In his classic and oft cited work entitled Public Opinion (1921) Walter Lippmann outlined in part the impact of newspapers in shaping public opinion. He stated as follows: "The newspapers are regarded by democrats as a panacea for their own defects, whereas analysis of the nature of news and of the economic basis of journalism seems to show that the newspapers necessarily and inevitably reflect, and therefore, in greater or lesser measure, intensify, the defective organization of public opinion" 15 . To be sure, his opinion of newspapers was not high, though his work demonstrated that newspapers were important to most of society. As Lippmann, described it, "The press services standardize the main events; it is only once in a while that a great scoop is made; there is apparently not a very great reading public for such massive reporting as has made The New York Times of recent years indispensable to men of all shades of opinion" (Lippmann 1922).

The media's role in shaping our perceptions is apparent. This is not a brand-new phenomenon, although today we have a wider and more extensive array of news media bombardment distributed at a continuous rate compared to earlier centuries. In the early 1970s, Maxwell E. McCombs and Donald L. Shaw discussed the impact that media has not only as a medium for politicians to communicate their policies and agendas to the public, but also in the opposite direction where the media can contribute to policies and political agendas as well (McCombs and Shaw, 1972, 176). They reference Lang and Cohen who stated that the media may not dictate what readers (or viewers or listeners) think about certain topics, but the media is able to dictate which topics to think about (McCombs and Shaw, 1972, 177). This was apparent in the nineteenth century in The New York Times regarding its portrayal of the Russian Empire and more specifically its portrayal of Russian Jews. Readers of the Times were presented with a topic that they were encouraged to have an opinion about, though were not forced to have a specific opinion. Importance of topics in newspapers is determined by "space and position" (McCombs and Shaw, 1972, 178), and articles pertaining to Russia in general between 1851 and 1905 were typically on page 4 out of 8 and often made their way to the front page. While this article does not emphasize the particular importance that readers of the Times placed on Russian Jews, it demonstrates that the Times deemed this a relevant and important topic, and topics that the media deem important correspond significantly to topics that individuals deem relevant and important.

McCombs and Shaw's analysis of media in the 1970s has relevance to the nineteenth century in terms of newspapers as the news media does in fact have biases and is able to set agendas (McCombs and Shaw, 1972, 176). Newspapers appeared daily and had lots of space and the agenda-setting ability of newspapers was partly due to the fact that, especially in the nineteenth century, people had few other options to obtain information about important happenings around the world other than through newspapers. David Weakliem furthered this point in his 2005 chapter entitled "Public Opinion, Political Attitudes, and Ideology" stating that public opinion has the ability to shape policy and detailed "policy feedback", i.e., the ability of policy to shape public opinion. He also stated that how topics are framed as the ability to alter public opinion quickly and effectively (Weakliem, 2005, 229-230).

15 Lippmann, W. (1921), "Newspapers Part VII" in Public Opinion. Accessed online e-book. https://gutenberg.org/cache/epub/6456/pg6456.html. Accessed on March 30, 2021. 
In the late 1800s and into the early 1900s The New York Times reported significantly on Russia's Jews. The Times was established in 1851 and although it had a specific niche in the newspaper market, for the first few decades, readership at times suffered, particularly due to economic depressions and recessions felt throughout the United States during the 1870s and 1890s. Publication increased drastically when the Times came under new ownership in 1896 after Adolf S. Ochs bought the company from one of the original partners, the other partner having died in the 1869. Ochs himself was the son of Jewish immigrants who immigrated to America from Germany. He fought against anti-Semitism along with many other prominent Jewish figures at the time including Oscar Straus, who in 1905 published an article that sought to debunk the historic friendly relationship between the United States and Russia, primarily to demonstrate that these two countries ought not hold affinity towards each other (Straus, 1905, 237-50).

The New York Times reported anti-Semitic rhetoric criticizing Russian Jews and how they did not assimilate well into American society and that the Jewish immigrants from Russia were a burden on American society as well as the already established Jewish community in America. Although the Times fashioned itself as an objective and fair newspaper, it was not immune to sensationalized "yellow" journalism that was in vogue in the nineteenth century. The Times itself under new ownership changed its general tone towards Russia and took a more philanthropic role, tending to write about Russia in a way that pitied its social conditions and began to distance from the earlier tone of boasting friendship and similarities between the U.S. and Russia. Likely stories outlining Jewish suffering in Russia appealed to readers and helped the Times sell more copies of their newspaper.

Most articles pertaining to Russian Jews outlined their suffering in Russia and the tsar's restrictions against them and The New York Times acted as a medium to illuminate the plight of Russian Jews; however, some articles criticized Russian Jews who immigrated to America, the same ones that the tsar had been persecuting. A significant increase in publications regarding Russian Jews occurred each time there was a spike in Jewish immigration to the United States. An increase in Russian Jewish immigration to the United States awakened the media and American perception of the Russian Empire, granted readers with intriguing news articles, and served the cause of prominent members of the Jewish faith who fought tirelessly to hold Russia accountable for its persecution of the Russian Jews. The Times was juxtaposed between humanitarian condemnation of the Russian tsar out of sympathy for Russian Jews and the call for the tsar to change his policies to dissuade Jews from continuing to immigrate to America. Further research can be done in the same topic yet more emphasis given to the role that media plays in shaping our perceptions and the impact that newspapers such as The New York Times concretely had on individual Americans and why Russia continues to be such a fascinating topic for American news media.

\section{References}

\section{Primary}

The New York Times, 1851-1905.

Joseph, S. (1914). Jewish Immigration to the United States from 1881 to 1910. New York: Columbia, USA.

Straus, O. S. (1905). "The United States and Russia: Their Historical Relations." The North American Review, 181 (585), pp. 237-250. 
WORLD COMPLEXITY SCIENCE ACADEMY JOURNAL| Vol. 2 Issue 1, 5 | Spring 2020

\section{Secondary}

Cognolato, M. (2016). "The Tsar's Power Explained to America: Notes from a 1905 Homily" in New Perspectives on Russian-American Relations Routledge, New York.

Dobkowski, M. N. (1977)."American Anti-Semitism: A Reinterpretation." American Quarterly, 29 (2), pp. 166-181.

Harrison, Benjamin. Third Annual Message. December 9, 1891. Congress. Online. https://millercenter.org/the-presidency/presidential-speeches/december-9-1891-third-annualmessage- 0 .

Higham, J. (1957). "Anti-Semitism in the Gilded Age: A Reinterpretation. The Mississippi Valley Historical Review 43 (4), pp. 559-578.

Knee, Stuart E. (1989). "The Diplomacy of Neutrality: Theodore Roosevelt and the Russian Pogroms of 1903-1906. Presidential Studies Quarterly, 19 (1), pp. 71-78.

Lippmann, W. (1921). "Newspapers Part VII" in Public Opinion. Accessed online e-book. https://gutenberg.org/cache/epub/6456/pg6456.html. Accessed on March 30, 2021.

McCombs, M. E., and Donald L. Shaw. "The Agenda-Setting Function of Mass Media." The Public Opinion Quarterly 36, no. 2 (1972), pp. 176-187.

Saul, Norman E. (1996). Concord and conflict: The United States and Russia, 1867-1914. Lawrence, Kan: University Press of Kansas, USA.

Weakliem, David L. 2005. "Public Opinion, Political Attitudes, and Ideology". The Handbook of Political Sociology. Cambridge University Press, New York, pp. 229-230.

This article is distributed under the terms of the Creative Commons Attribution 4.0 License (https://creativecommons. org/licenses/by/4.0/) which permits any use, reproduction and distribution of the work without further permission provided the original work is attributed as specified on the WCSA Journal by World Complexity Science Academy (https://www.wcsaglobal.org/ethics-policy/). 